\title{
The influence of entrepreneurial capital on social transformation by social enterprises in Kiambu County, Kenya
}

\author{
Njenga, Francis Kigo, Kitonga, Daniel M, Gatumo, Francis M
}

\begin{abstract}
Several studies have found entrepreneurial capital or finance to be significant in growth and performance of enterprises. This development has led the researchers in the present study to investigate the role of entrepreneurial capital in social transformation by social enterprises in Kiambu County, Kenya. This journal examines the influence of entrepreneurial capital on social transformation. The context of the study was Kiambu County, Kenya. Social entrepreneurship theory, market failure theory, empowerment theory, planned behavior theory and cultural dimension's theory guided the study. The study used a descriptive survey design guided by a mixed methods research approach. The sample size was 322 social enterprises drawn from a target population of 1944 social enterprises distributed all from Kiambu County. Data was collected using survey questionnaires and interview guide instruments. Simple random sampling technique was used to get the proportionate sample for each strata. Data was descriptively and inferentially presented and analyzed. The findings shows $R$-value of $.614, R^{2}$ value of .377 , adjusted $R^{2}$ value of .375; F-statistics value is 1977.052 greater than critical value of 3.85 and $p$-value was 0.000 . The study concludes that entrepreneurial capital has a statistically significant and positive effect on social transformation by social enterprises.
\end{abstract}

Keywords: Entrepreneurial capital, social transformation, social enterprises

\section{Introduction}

Enough evidence exists to support the view that social entrepreneurship emerged in the 1980s with the establishment of Ashoka, which is concerned with supporting social entrepreneurs across the world (Ashoka, 2017). Ahrari, et al., (2018, p. 495), noted that rural social enterprises assist in social transformation by identifying and solving social problems. This argument is supported by the fact that social enterprises in rural societies interact with rural communities to generate social innovation (Richter, 2017). Ultimately, studies have found that most rural social enterprises focus on supporting the underprivileged in rural areas through provision of goods and services and employment opportunities (Parker, 2018).

Accordingly, Linna, (2011, p. 10), at the bottom of the pyramid (BOP), cooperatives and other institutions or Organisations are popular in addressing social needs. This characterization is congruent with purpose of this study to investigate the influence of social enterprises on social transformation in Kiambu County. The emergence of social entrepreneurship in Africa has been linked to Ubuntu philosophy, which emphasises interdependence and reciprocity over individualism and self-interest, and to a cultural belief in putting tribal interests above individual gain (Chilufya \& Kerlin, 2017). Most of these studies on social enterprises/social entrepreneurship seems to indicate the necessity of social enterprises in solving societal problems. Thus, the current study sought to produce evidence on the presence and impact of social enterprises in Kiambu County, Kenya.

\section{Literature Review}

The following is a critical thematic review of literature on entrepreneurial capital and social transformation.

Entrepreneurial capital and social transformation: A thematic review

Over the years, an enormous amount of research has been carried out in an attempt to highlight the role of entrepreneurial capital in social change. The concept of entrepreneurial capital suggests that the entrepreneurial process is influenced by financial capital as well as by other types of capital owned or 
accessed by the entrepreneur (Firkin, 2003). These resources include human capital, social capital, symbolic capital, human capital, physical capital, organizational capital, and technological capital (Boden \& Nucci, 2000; De Carolis \& Saparito, 2006). These types of capital have influence on the overall performance of the firm (Firkin, 2003; Davidson \& Honig, 2003). These arguments justify the inclusion of entrepreneurial capital in a study of social enterprises.

However, the debate has not subsided yet. For instance, Burge, (2017), proposed a model with five variables based on the literature to determine the relationship between demographic, human capital, and social capital characteristics of nascent entrepreneurs and expected job growth in the United States: age, gender, education level, knowing other entrepreneurs, and previous business angel investing experience. From the study by Burge, ample evidence exists to support the view that entrepreneurial capital is essential for social entrepreneurs and social transformation.

Likewise, Basu, (2017), established that in the poor socio-economic context of India, social entrepreneurs, can reproduce social capital and sustain an organisation if they follow the 'enabling leadership' style. Basu concluded that according to the findings of the three case studies in the poor socio-economic context of India, the social entrepreneur leaders in community organisations played a role of 'enabler' leader. The role of entrepreneurial capital on social transformation has been largely overlooked hence the use of this variable in the current study.

In addition, Lauzikas and Dailydaite, (2012), conducted a study on 'Impacts of social capital on transformation from efficiency to innovation-driven businesses. These two scholars explain, the key aspects of social capital as entrepreneurs often ignore social relations, usage of human capital in innovation processes, and expertise in market analysis. Lauzikas and Dailydaite analysed the relation between social capital and transformation from efficiency to innovation-driven business. Lauzikas and Dailydaite relied on Global Entrepreneurship Monitor (GEM) methodology, which combines quantitative adult survey and qualitative expert interviews in the context of analysing the effects of social capital in the case of Lithuania. This study is informative in terms of the role of social capital in the study although it did not use the GEM methodology. Further, Light and Dana, (2013), conducted a study on 'Boundaries of Social Capital in Entrepreneurship' and suggested that social capital promotes entrepreneurship only when supportive cultural capital is in place (p. 15). The study by Light and Dana is congruent with Bourdieu (1986) who identified four forms of capital namely: economic, social, cultural and symbolic.

According to Firkin (2003), entrepreneurial capital encompasses various tangible and intangible resources, which make up an entrepreneur's capital stock. Similarly, Firkin, (pp. 59-60), categorized entrepreneurial capital as comprising: financial capital, human capital, social capital, organizational capital, physical capital and technological capital. Resource capability is fundamental to the success of any venture. In line with this claim, Klein, et al., (2013, p. 70), concluded that an organization's capabilities were critical to entrepreneurial behavior and performance. Resources are important in achieving a ventures' mission. However, entrepreneurs are not limited by the resources they control but by the mission. One important key resource for social enterprises is human capital. Social enterprises depend heavily on human capital for their success. The most used capital in social enterprises is human capital (volunteers) and social capital (partnerships/ collaborations). There has been criticism on the use of human capital despite the fact that volunteers have been valuable resource to some service organizations where financial capital to hire sufficient personnel is limited. However, the negativity of depending on volunteer human capital in many organizations has been the high staff turnover rate especially when it comes abruptly leaving the organization in a stalemate (Doherty, et al., 2014). Above all, it is noted, that not all volunteers possess vital energy and at times relevant skills to influence the achievement of the mission and vision of a social enterprise.

Social enterprises require a diverse type of capital to fulfill their mission. Financial resources are a major constraint for many enterprises including social enterprises. The current study sought to find out how this is a factor among social enterprises in Kiambu County. According to Mutai, (2011), lack of access to funding by small and micro enterprises undermines their operations.

Likewise, a study by Smith and Darko, (2014, p. 15), observed that social enterprises in Kenya and Vietnam established that access to finance was a major challenge. Similarly, Cornforth, $(2014$, p. 11), stated that social enterprises have the responsibility of ensuring that they achieve their mission and remain financially sustainable. These studies addressed the issue of mission in social enterprises, which were a concern for the study. Accordingly, Jenner and Oprescu (2016), retorted that a social entrepreneur positively develops new 
social values in collaborating with employees, volunteers, and the target population, thereby enabling solidarity, collaboration, and social capital to sustain the organization of the social enterprise. The usefulness of social capital in social enterprise is verified by the relationship between employees (Furmańska-Maruszak \& Sudolska, 2017), the survival of social enterprise, form of employment (Bouchard \& Rousselière, 2016), and the intrinsic forces and partnerships for social purposes (Sdrali, et al., 2016). These studies agree that social capital is vital for the success of social entrepreneurs.

Further, according to Balasu (2017), in a study on the management of social enterprises in Ghana: Challenges and strategies, six themes for challenges and five themes for strategies were identified. The thematic challenges identified includes: finance/ investment, minimum understanding/ low awareness, human resources, eco-system, mission drift, and governance. The current study did not focus on challenges facing social enterprises, but on how social enterprises impact social transformation. It is evident from the discussions by scholars on this subject that achieving social transformation is not possible without different human capital, financial and non-financial capital which though not an end by themselves but are means to influence the rate of social transformation. For this reason, the current study was undertaken to determine the influence of entrepreneurial capital on social transformation by social enterprises in Kiambu County, Kenya.

It is agreeable that individual-level resources within a social enterprise, plays an important role in achieving the desired social transformation (Brieger \& De Clercq, 2019). It is necessary to identify the key resources that enable a social enterprise to achieve and sustain her mission. In addition it is noticeable that financial, human, and social capital have strong influences on social and commercial entrepreneurial activities (Kachlami, et al., 2018). However, this study investigated how the three forms of capital contribute to social transformation in Kiambu County, Kenya. Thus, the study sought to understand how availability of entrepreneurial capital contributes wholistically to social transformation by social enterprises in Kiambu County, Kenya.

\section{Methods}

A descriptive study design was appropriate for this study because it enabled the researchers to engage the social enterprises in their natural contexts in Kiambu County. The choice of this design is informed by the fact that social entrepreneurial practices reside within people or individuals and is exemplified in their entrepreneurial actions and outcomes. Descriptive research design was fitting in the current study as it is concerned with the individual characteristics of the social entrepreneurs within their social enterprises. According to Creswell (2002), descriptive research design is used when collecting information about people's attitude, opinions and habits and is appropriate for analyzing social behavior and patterns.

The County of Kiambu is the bedroom for many workers from Nairobi County. This scenario has overstretched vital human services as health, sanitation, poverty, education, and business among others. The County many inhabitants engaged in diverse initiatives among which social enterprises are accounted to be approximately over 1944 addressing complex social problems. The target population for the study was composed of 1944 social enterprises from which 322 social enterprises were sampled for the study (Krejcie $\&$ Morgan, 1970). The chosen social enterprises were those engaged in a social mission, namely solving one or more social problems in the society.

Probability and non-probability sampling techniques were adopted in the study. First, purposive sampling was used to select Kiambu County; secondly, stratified sampling technique was used to stratify the social enterprises according to the 12 sub-counties forming Kiambu County. Stratified sampling enabled the researchers to obtain a representative sample of all the social enterprises from the target sub-counties. This enabled the possibility of reducing the standard error by providing control over the variance. Data was collected through the use of survey questionnaires and interview guides. Quantitative data was examined through descriptive statistics and inferential statistics while qualitative data from the interviews was thematically organized, analyzed and presented in narrative forms.

\section{Results}

\section{Response Rate}

The response rate is the level of individuals who responded to a study. According to Orodho, (2003), the response rate is the degree to which the final data sets incorporate all sampled individuals and is determined as the number of respondents with whom interviews are completed and divided by the absolute number of 
respondents of the whole sample including none respondents. This study sampled 322 social enterprises. The researcher distributed 322 questionnaires. The response and non-response rate are presented in Table 1.

Table 4.1: Response Rate

\begin{tabular}{|l|l|l|}
\hline Questionnaire & Frequency & Percentage \\
\hline Returned & 285 & $88.5 \%$ \\
\hline Not Returned & 27 & $11.5 \%$ \\
\hline Total & $\mathbf{3 2 2}$ & $\mathbf{1 0 0 \%}$ \\
\hline
\end{tabular}

According to Table 1, from the 322 questionnaires distributed, 285 were returned. From the questionnaires returned, the overall response rate is $88.5 \%$ against a non-response rate of $11.5 \%$. The non-response rate of $11.5 \%$ was insignificant following the comment of Kothari (2004), who indicates that a response rate of $50 \%$ is normal and a response rate between $60-70 \%$ is satisfactory while anything above $70 \%$ is an excellent response rate. This response rate was, thusly, is thought to be an acceptable representation of the sample to provide sufficient findings for analysis and to infer the conclusions about the study variables.

\section{Respondents Gender Distribution}

The study sought to identify the gender distribution of the participants of the study. The results on this question are presented in Table 2.

Table 2. Gender Distribution

\begin{tabular}{|l|l|c|c|}
\hline \multicolumn{2}{|c|}{ Gender } & Frequency & Percent \\
\hline \multirow{2}{*}{ Vali } & Male & 128 & 44.9 \\
\cline { 2 - 4 } & Female & 157 & 55.1 \\
\cline { 2 - 4 } & Total & $\mathbf{2 8 5}$ & $\mathbf{1 0 0 . 0}$ \\
\hline
\end{tabular}

From the results on gender, as presented in Table 2, the researchers concluded that the participants in the study were either male or female. The participation in regards to gender and as depicted in Table 2 shows that $55.1 \%$ (157) were females while $44.9 \%$ (128) were males. These results indicate that the participants were from either gender.

\section{Social Enterprise Age}

The study sought to find the age of the social enterprises represented in this study. The results presented in Table 3. Social enterprises' age was measured in terms of the number of years of operation of the social enterprise.

Table 3. Age distribution of social enterprises

\begin{tabular}{|l|l|c|c|}
\hline \multicolumn{2}{|c|}{ Age Range } & $\begin{array}{c}\text { Frequen } \\
\text { cy }\end{array}$ & Percent \\
\hline \multirow{4}{*}{ Valid } & 0-5 years & 171 & 60.0 \\
\cline { 2 - 4 } & 6-10 years & 63 & 22.1 \\
\cline { 2 - 4 } & 11-20 years & 31 & 10.9 \\
\cline { 2 - 4 } & Above 21 years & 20 & 7.0 \\
\cline { 2 - 4 } & Total & 285 & 100.0 \\
\hline
\end{tabular}

Table 3 indicates that, $31.3 \%$ of the social enterprises had existed for more than 20 years, $28.1 \%$ had been in operation for 6 to 10 years, and 24.2\% had been in operation for between 11 to 20 years while $16.4 \%$ had operated for a period of 0 to 5 years. The distribution of these firms for the years they have been in operation is as shown in Table 3.

\section{Regression Analysis for Entrepreneurial Capital and Social Transformation}

The result of the regression analysis for entrepreneurial capital with social transformation by social enterprises was done and the model summary is presented in Table 1.

Table 4. Regression for entrepreneurial capital and social transformation

\begin{tabular}{|l|c|c|c|c|}
\hline $\begin{array}{l}\text { Mo } \\
\text { del }\end{array}$ & $\mathbf{R}$ & $\mathbf{R}$ & $\begin{array}{c}\text { Adjusted R } \\
\text { Square }\end{array}$ & $\begin{array}{c}\text { Std. Error of the } \\
\text { Estimate }\end{array}$ \\
\hline
\end{tabular}




\begin{tabular}{|l|c|c|c|c|}
\hline 1 & $.614^{\mathrm{a}}$ & .377 & .375 & 9.82650 \\
\hline \multicolumn{2}{|l|}{ a. Predictors: (Constant), ECAP } \\
\hline
\end{tabular}

The results in Table 4 indicate $R$-value of $.614, R^{2}$-value of .377 , adjusted $R^{2}$-value of .375 with an estimated standard error value of 9.82650 .

Table 5. ANOVA for entrepreneurial capital and social transformation

\begin{tabular}{|l|l|l|l|l|c|c|}
\hline \multicolumn{2}{|l|}{ Model } & $\begin{array}{l}\text { Sum } \\
\text { Squares }\end{array}$ & df & $\begin{array}{l}\text { Mean } \\
\text { Square }\end{array}$ & F & Sig. \\
\hline 1 & $\begin{array}{l}\text { Regressi } \\
\text { on }\end{array}$ & 19027.318 & 1 & 19027.318 & $\begin{array}{c}197.05 \\
2\end{array}$ & $.000^{\mathrm{b}}$ \\
\cline { 2 - 6 } & Residual & 31478.594 & 326 & 96.560 & & \\
\cline { 2 - 7 } & Total & 50505.912 & 327 & & & \\
\hline
\end{tabular}

The Analysis of Variance for entrepreneurial capital with social transformation by social enterprises in Table 5 indicate the computed F-Statistics value is 1977.052 greater than critical value of 3.85 and $p$-value was 0.000 .

Table 6. Coefficients for entrepreneurial capital and social transformation

\begin{tabular}{|c|c|c|c|c|c|c|}
\hline \multirow{2}{*}{\multicolumn{2}{|c|}{ Model }} & \multicolumn{2}{|c|}{$\begin{array}{c}\text { Unstandardized } \\
\text { Coefficients }\end{array}$} & \multirow{2}{*}{$\begin{array}{c}\begin{array}{c}\text { Standardized } \\
\text { Coefficients }\end{array} \\
\text { Beta }\end{array}$} & \multirow[t]{2}{*}{$\mathbf{t}$} & \multirow[t]{2}{*}{ Sig. } \\
\hline & & B & $\begin{array}{c}\text { Std. } \\
\text { Error }\end{array}$ & & & \\
\hline \multirow[t]{2}{*}{1} & $\begin{array}{l}\text { (Constan } \\
\text { t) }\end{array}$ & 10.152 & 2.799 & & 3.627 & .000 \\
\hline & ECAP & .404 & .029 & .614 & 14.038 & .000 \\
\hline
\end{tabular}

Table 6 shows beta coefficient .614 , $t$-values of 3.627 and 14.038 with $p$-values being 0.000 .

\section{Correlation for Entrepreneurial Capital and Social Transformation}

A correlation analysis between entrepreneurial capital and social transformation was performed. The correlation results are presented in Table 6.

Table 7. Correlations for Entrepreneurial Capital and Social Transformation

\begin{tabular}{|c|c|c|c|}
\hline & ST & ECAP \\
\hline \multirow[t]{3}{*}{ ST } & Pearson Correlation & 1 & $.614^{* * *}$ \\
\hline & Sig. (2-tailed) & & .000 \\
\hline & $\mathrm{N}$ & 328 & 328 \\
\hline \multirow{3}{*}{$\begin{array}{l}\text { EC } \\
\text { AP }\end{array}$} & Pearson Correlation & $.614^{* * *}$ & 1 \\
\hline & Sig. (2-tailed) & .000 & \\
\hline & $\mathrm{N}$ & 328 & 328 \\
\hline
\end{tabular}

Table 7 indicate the correlation results between entrepreneurial capital and social transformation where $r$ $=.614$ significant at the 0.01 (2-tailed).

\section{Discussions}

The results in Table 4 indicate there is relationship between entrepreneurial capital and social transformation by social enterprises in which $R^{2}$ was 0.377 implying that $37.7 \%$ of the variation in entrepreneurial capital and social transformation by social enterprises is explained by entrepreneurial capital. This shows that an increase in entrepreneurial capital by SEs by one unit causes an increase in social transformation by SEs by 0.614 of a unit. The adjusted $R$ square of 0.375 means that entrepreneurial capital without the constant explains $37.5 \%$ variation in social transformation by social enterprises. The remaining $62.5 \%$ variation in social transformation by social enterprises is explained by other variables, which were not in this model. 
Likewise, the results in Table 5 indicate the $p$-value is less than 0.05 meaning that the relationship between entrepreneurial capital and social transformation by social enterprises is significant. Thus, the null hypothesis is rejected and concluded that there is a significant strong relationship between entrepreneurial capital and social transformation by social enterprises in Kiambu County.

Further, the results in Table 6 indicate the p-value was less than 0.05 hence the model is statistically significant. The model is defined as $Y=10.152+0.61 X_{2}+e$, indicating that every unit increase in entrepreneurial capital leads to 0.614 increase in social transformation by social enterprises. This implies that entrepreneurial capital positively affects social transformation by social enterprises in Kiambu County. The results in Table 6 reveal there is a significant correlation between entrepreneurial capital and social transformation by social enterprises as a result of the $p$-value of 0.000 , which is less than 0.05 and Pearson Correlation coefficient was 0.614 while other independent variables were held constant.

These results signify that there was a significant relationship between entrepreneurial capital and social transformation by social enterprises. The positive coefficient of correlation value implies that there is a positive strong relationship between entrepreneurial capital and social transformation by SEs in Kiambu County, that is, as the social enterprises increase entrepreneurial capital the social transformation by the social enterprises increases. The study concluded that there is a significant strong positive relationship between entrepreneurial capital and social transformation by SEs in Kiambu County, Kenya.

The findings in the present study find support from previous studies that delved on investigating entrepreneurial capital and firm performance. For instance, Firkin (2003) argues that, the entrepreneurial process is influenced by financial capital as well as by other types of capital owned or accessed by the entrepreneur. These resources include human capital, social capital, symbolic capital, human capital, physical capital, organizational capital, and technological capital (Boden \& Nucci, 2000; De Carolis \& Saparito, 2006; Haber \& Reichel, 2007; Casson \& Giusta, 2007). These types of capital have influence on the overall performance of the firm (Firkin, 2003; Davidson \& Honig, 2003). Likewise Burge, (2017), proposed inclusion in these discussion variables such as age, gender, education level, knowing other entrepreneurs and previous business angel investing experience as components of entrepreneurial capital, which are essential for social entrepreneurs and social transformation.

More so, Lauzikas and Dailydaite (2012), explains that the key aspects of social capital as entrepreneurs often ignore social relations, usage of human capital in innovation processes, and expertise in market analysis. In addition, Light and Dana (2013) suggested that social capital promotes entrepreneurship only when supportive cultural capital is in place (p. 15). This view is congruent with Bourdieu (1986) who recognized four forms of capital, namely: economic, social, cultural and symbolic. Similarly, Klein, et al., (2013, p. 70), noted that an organization's capabilities were critical to entrepreneurial behavior and performance. Resources are important in achieving a ventures' mission. However, entrepreneurs are not limited by the resources they control but by the mission.

Likewise, Jordan, et al., (2010, p. 145), observed the factors of social capital as being: locations with greater human capital, employment opportunity, income, and a stable population with better resources and infrastructure. Social enterprises require a diverse type of capital to fulfill their mission. Financial resources are a major constraint for many enterprises including social enterprises. Accordingly, Fal, (2013), confirmed that access to capital was a challenge for many enterprises hence the main sources of capital for small and growing enterprises were retained earnings, loan associations, and investments from family and friends. Likewise, a study by Smith and Darko, (2014, p. 15), observed that social enterprises in Kenya and Vietnam established that access to finance was a major challenge. Similarly, Cornforth, $(2014$, p. 11), stated that social enterprises have the responsibility of ensuring that they achieve their mission and remain financially sustainable. These studies addressed the issue of mission in social enterprises, which were a concern for the study.

Accordingly, Jenner and Oprescu, (2016), retorted that a social entrepreneur positively develops new social values in collaborating with employees, volunteers, and the target population, thereby enabling solidarity, collaboration, and social capital to sustain the organization of the social enterprise. The usefulness of social capital in social enterprise is verified by the relationship between employees (Furmańska-Maruszak \& Sudolska, 2016), the survival of social enterprise, form of employment (Bouchard \& Rousselière, 2016), and the intrinsic forces and partnerships for social purposes (Sdrali, et al., 2016). These studies agree that social capital is vital for the success of social entrepreneurs. 


\section{$\mathrm{H}_{02}$ : There is no significant association between entrepreneurial capital and social Transformation in Kiambu County, Kenya}

\section{Ha2: Entrepreneurial capital has significant relationship with social transformation in Kiambu County, Kenya.}

This was tested using simple regression analysis, and where the regression model estimate revealed that entrepreneurial capital is statistically significant at $\beta=0.777 ; t=11.468 ; p=0.00$. Hence, at $95 \%$ level of confidence, entrepreneurial capital has a positive statistically significant effect on social transformation. These results illustrate that a unit increase in entrepreneurial capital is responsible for increasing social transformation by 0.777 . This study concludes that there is a positive statistical significant relationship between entrepreneurial capital and social transformation by social enterprises in Kiambu County.

This finding is in line Bunyasi, et al., (2017), who noted that access to entrepreneurial finance has a positive influence on the growth of SMEs since it has a positive correlation (p. 118). Bunyasi, et al., tested the significance of entrepreneurial finance to the growth of SMEs. From the results the $p$-value $(0.000)$ is less than the level of significance (0.05) implying that the model is significant. Additionally, the $F$ computed 16.862 is greater than the $F$-critical (3.84) which implies that the model $Y=14.013+0.388 X_{3}$ in which is significant and therefore good for prediction.

Bunyasi, et al., used Pearson product moment correlation to assess the relationship between access to finance and growth of SMEs and established that there was a positive correlation between the variables, $r=0.339, n=132, p=0.000$. Further, Bunyasi, et al., found that the $p$-value was less than 0.05, level of significance which implied that access to finance was very significant and greatly influences the growth of SMEs (p. 117). Bunyasi, et al., also established that the $R=0.339$ and the $R^{2}$ value of 0.115 or $11.5 \%$ shows that $11.5 \%$ of the variation in growth of SMEs is explained by variation in access to entrepreneurial finance (p. 117). Bunyasi, et al., findings indicated that access to entrepreneurial finance has a positive influence on the growth of SMEs since it has a positive correlation .which is in agreement with this study on Kiambu County.

\section{Conclusion}

The objective of the study was to determine the association between entrepreneurial capital and social transformation by social enterprises in Kiambu County. The study was able to detect a relationship between entrepreneurial capital and social transformation by social enterprises in Kiambu County. Equally, the correlation and regression analysis revealed a statistically significant relationship between entrepreneurial capital and social transformation in terms of human capital, bonding capital and financial capital at 0.01 level of significant. From these results, there is agreement that entrepreneurial capital is a factor that determines the social transformation by social enterprises. The results confirm what other studies, identified in this article have alluded that entrepreneurial finance/capital enhances the performance of an enterprise.

\section{Areas for further research}

The study recommends that further research where a census on all social enterprises is done to give true picture of this growing sector. Both the County government and the National government need to introduce financial incentives for social entrepreneurs, which help them to engage more in social transformation.

\section{References}

1. Balasu, D. S. K. (2017). Management of social enterprises in Ghana: Challenges and strategies. Dissertation, MSc in Business and Management

2. Basu, S. (2012). Social capital and social entrepreneurship: Analysing links. Interdisciplinary Journal of Contemporary Research in Business, 4(3), 386-405.

3. Boden, R. J. \& Nucci, A. R. (2000) 'On the survival prospects of men's and women's new business ventures', Journal of Business Venturing, 15(4), pp. 347-362.

4. Bouchard, M. J., \& Rousselière, D. (2016). Do hybrid organizational forms of the social economy have a greater chance of surviving? An examination of the case of Montreal. VOLUNTAS: International Journal of Voluntary and Nonprofit Organizations, 27(4), 1894-1922.

5. Creswell, J. W. (2002). Educational research: Planning, conducting, and evaluating quantitative. Upper Saddle River, NJ: Prentice Hall. 
6. Davidsson, P. \& Honig, B. (2003) 'The role of social and human capital among nascent entrepreneurs'. Journal of Business Venturing, 18(3), pp. 301-331.

7. De Carolis, D. M. \& Saparito, P. (2006). 'Social capital, cognition, and entrepreneurial opportunities: A theoretical framework'. Entrepreneurship: Theory and Practice, 30(1), pp. 41-56.

8. De Clercq, D., Brieger, S. A., \& Welzel, C. (2019). Leveraging the macro-level environment to balance work and life: an analysis of female entrepreneurs' job satisfaction. Small Business Economics, 1-24.

9. Firkin, P. (2003). 'Entrepreneurial Capital' In: de Bruin, A. \& Dupuis, A. (ed.) Entrepreneurship: New Perspectives in a Global Age. Aldershot, United Kingdom: Ashgate, pp. 57-75.

10. Furmańska-Maruszak, A., \& Sudolska, A. (2017). Making Work Sustainable in Business and Social Enterprises. ECONOMIC, 261.

11. Jenner, P., \& Oprescu, F. (2016). The sectorial trust of social enterprise: friend or foe? Journal of Social Entrepreneurship, 7(2), pp. 236-261.

12. Kachlami, H., Yazdanfar, D., \& Öhman, P. (2018). Regional demand and supply factors of social entrepreneurship. International Journal of Entrepreneurial Behavior \& Research.

13. Krejcie, R. V., \& Morgan, D. W. (1970). Determining sample size for research activities. Educational and psychological measurement, 30(3), 607-610.

14. Laužikas, M., \& Dailydaite, S. (2015). Impacts of social capital on transformation from efficiency to innovation-driven business. Journal of Business Economics and Management, 16(1), 37-51.

15. Mutai, R. (2011). Micro and small enterprise sector and existing support system with emphasis on high-tech oriented entrepreneurship in Kenya. Journal of Language, Technology \& Entrepreneurship in Africa, 3(1), pp. 99-108.

16. Sdrali, D., Goussia-Rizou, M., Giannouli, P., \& Makris, K. (2016). What motivates employees to engage in the social economy sector? A case study of Greek cooperative enterprises. International Journal of Social Economics.

17. Smith, W., \& Darko, E. (2014). Social enterprise: constraints and opportunities-evidence from Vietnam and Kenya. ODI. www. odi. org/publications/8303-social-enterpriseconstraintsopportunities-evidence-vietnam-kenya. 